\title{
Is Asacol as effective as sulphasalazine in maintaining remission of Crohn's disease and ulcerative colitis?
}

\author{
Imad M. Nakshabendi, Andrew Duncan and Robin I. Russell
}

Gastroenterology Unit, Royal Infirmary, Glasgow G31 2ER, UK

\begin{abstract}
Summary: To compare the efficacy of Asacol (mesalazine coated with Eudraget-S) as a maintenance therapy with that of sulphasalazine, relapse rates of patients with ulcerative colitis and Crohn's disease, treated with sulphasalazine or Asacol were assessed in a retrospective study. A total of 164 patients were investigated, 127 on sulphasalazine and 37 on Asacol. None of the patients on Asacol was changed from sulphasalazine because of lack of efficacy to sulphasalazine. Relapse rates were measured over a 4 year period. In ulcerative colitis these were sulphasalazine 10/77 (13.0\%), Asacol 5/20 (25.0\%), NS; in all Crohn's disease patients, sulphasalazine 12/50 (24.0\%), Asacol 11/17 (64.7\%); $P<0.0025$. In patients with Crohn's disease with ileal involvement, relapse rates were sulphasalazine 9/28 (32.1\%), Asacol 9/11 $(81.6 \%), P<0.0125$; without ileal involvement, sulphasalazine $3 / 22(13.6 \%)$, Asacol $2 / 6(33.4 \%)$, NS.

This study suggests that Asacol is as effective as sulphasalazine in maintaining remission in ulcerative colitis and in patients with Crohn's disease without ileal involvement. Sulphasalazine seems to be more effective than Asacol in maintaining remission in patients with Crohn's disease with terminal ileal involvement.
\end{abstract}

\section{Introduction}

Sulphasalazine is an effective agent for maintaining remission in ulcerative colitis (UC) ${ }^{1}$, and is also used to induce remission in mild to moderately active disease. ${ }^{2}$ It was developed in the 1930s and first used in UC in $1942 .{ }^{3}$ When it is taken orally nearly all the dose reaches the colon intact where it is split by bacteria into sulphapyridine and 5aminosalicylic acid which is the active moiety. ${ }^{4}$ However, sulphapyridine and its metabolites account for most of the side effects of sulphasalazine. ${ }^{5}$

Although 5-aminosalicylic acid has been proven to be effective topically it needs a delivery system for oral use since it is absorbed in the small intestine. ${ }^{6}$ For this reason delayed or slow-release preparations were developed. One of these preparations was achieved by. coating 5-aminosalicylic acid with a pH-dependent acrylic resin. Asacol, which is 5-aminosalicylic acid coated with Eudraget-S, is an example of this approach which theoretically allows the release of 5-aminosalicylic acid in the relative alkalinity of the distal ileum and proximal colon. ${ }^{7}$ However, 5 -aminosalicylic acid is not always released in the terminal ileum, indeed on some occasions the whole tablet was passed intact

Correspondence: I.M. Nakshabendi, M.R.C.P. Accepted: 11 October 1991 in the stool. Hence it is less likely to benefit patients with small bowel disease. ${ }^{7}$

The aim of this study is to compare the efficacy of Asacol with that of sulphasalazine in maintaining remission in inflammatory bowel disease, with particular reference to patients with terminal ileal abnormalities.

\section{Patients and methods}

Case records were reviewed of patients with an established diagnosis of ulcerative colitis and Crohn's disease attending the Gastroenterology Outpatient Department at the Royal Infirmary, Glasgow, over a 4 year period. Only those patients with a definitive diagnosis and who were on maintenance therapy with either sulphasalazine or Asacol were included in the study. Patients on Asacol were either initially started on it or changed from sulphasalazine because of intolerance or development of adverse effects; none was changed to Asacol because of lack of effect of sulphasalazine. Both groups were comparable regarding sex, age and duration of their disease (Table I). The extent of disease and number of patients admitted to hospital with exacerbation of disease are shown in Table II. Admission to hospital was taken as the point when the disease activity was 
Table I Patients investigated with ulcerative colitis (UC) and Crohn's disease (CD) on sulphasalazine and Asacol

\begin{tabular}{|c|c|c|c|c|}
\hline & \multicolumn{2}{|c|}{ Sulphasalazine } & \multicolumn{2}{|c|}{ Asacol } \\
\hline & $U C$ & $C D$ & $U C$ & $C D$ \\
\hline Number of patients & 77 & 50 & 20 & 17 \\
\hline Male/female & $34 / 43$ & $15 / 35$ & $8 / 12$ & $7 / 10$ \\
\hline \multicolumn{5}{|l|}{ Age } \\
\hline Range (y) & $14-80$ & $16-83$ & $21-56$ & $18-69$ \\
\hline Average (y) & 50.55 & 40.46 & 39.85 & 35.12 \\
\hline \multicolumn{5}{|l|}{ Disease duration } \\
\hline$<10 y$ & 35 & 35 & 11 & 15 \\
\hline$>10 y$ & 42 & 15 & 9 & 2 \\
\hline \multicolumn{5}{|l|}{ Treatment } \\
\hline Duration & $>6$ months & & $>6$ months & \\
\hline Dose & $2.0 \mathrm{~g} /$ day & & $1.2 \mathrm{~g} / \mathrm{day}$ & \\
\hline
\end{tabular}

Table II Extent of disease and admission to hospital

\begin{tabular}{lcr}
\hline Disease extent & Sulphasalazine & Asacol \\
\hline Ulcerative colitis & & \\
Distal & $53(4)^{*}$ & $13(3)$ \\
Left side & $15(3)$ & $4(2)$ \\
Pancolitis & $9(3)$ & $3(0)$ \\
Crohn's disease & & \\
Ileocaecal & $22(8)$ & $9(8)$ \\
Colonic & $19(2)$ & $6(2)$ \\
Ileal & $3(0)$ & $2(1)$ \\
Other sites & $6(2)$ & $0(0)$ \\
\hline
\end{tabular}

*Figures in parentheses represent the numbers of patients admitted to hospital.

severe enough to be considered as a relapse. Due to the nature of the study it was difficult to calculate the exact activity index. The exacerbation rate was calculated by dividing the number of patients with relapse by the total number of patients on maintenance therapy. The statistical methods used were Fisher's exact probability test and Chi-square $\left(\chi^{2}\right)$ test as appropriate.

\section{Results}

Relapse rates of the patients are shown in Table III. The relapse rate of all patients with inflammatory bowel disease on Asacol (43.2\%) was significantly higher than that in patients on sulphasalazine $(17.3 \%)(P=0.001)$. Patients with ulcerative colitis who were on sulphasalazine had a relapse rate of $13.0 \%$, showing no statistical difference from the relapse rate of patients on Asacol (25.0\%). In the Crohn's disease group the difference in relapse rate was higher in the Asacol group when the terminal ileum was involved $(81.6 \%)$ compared with
Table III Relapse rate in various groups studied

\begin{tabular}{|c|c|c|c|}
\hline $\begin{array}{l}\text { Disease } \\
\text { group }\end{array}$ & $S S Z$ & Asacol & $\mathrm{P}$ value \\
\hline IBD & $\begin{array}{c}22 / 127 \\
(17.3 \%)\end{array}$ & $\begin{array}{c}16 / 37 \\
(43.2 \%)\end{array}$ & 0.001 \\
\hline UC & $\begin{array}{c}10 / 77 \\
(13.0 \%)\end{array}$ & $\begin{array}{c}5 / 20 \\
(25.0 \%)\end{array}$ & N.S. \\
\hline CD & $\begin{array}{c}12 / 50 \\
(24.0 \%)\end{array}$ & $\begin{array}{c}11 / 17 \\
(64.7 \%)\end{array}$ & 0.0025 \\
\hline $\begin{array}{l}\text { CD-ileum } \\
\text { involved }\end{array}$ & $\begin{array}{c}9 / 28 \\
(32.1 \%)\end{array}$ & $\begin{array}{c}9 / 11 \\
(81.6 \%)\end{array}$ & 0.0125 \\
\hline $\begin{array}{l}\text { CD-ileum } \\
\text { not involved }\end{array}$ & $\begin{array}{c}3 / 22 \\
(13.6 \%)\end{array}$ & $\begin{array}{c}2 / 6 \\
(33.4 \%)\end{array}$ & N.S. \\
\hline
\end{tabular}

IBD = Inflammatory bowel disease; $S S Z=$ sulphasalazine; $\mathrm{UC}=$ ulcerative colitis; $\mathrm{CD}=$ Crohn's disease; N.S. = not significant .

$(32.1 \%)$ in the sulphasalazine group $(P=0.0125)$ In Crohn's disease without ileal involvement, there was no statistically significant difference in relapse rate between Asacol (33.4\%) and sulphasalazine $(13.6 \%)$.

\section{Discussion}

Delayed-release mesalazine is an effective treatment for maintaining ulcerative colitis remission. ${ }^{7,8}$ It is also associated with fewer side effects than equivalent doses of enteric-coated sulphasalazine. ${ }^{9}$ The present study shows that delayed-release mesalazine (Asacol) is as effective as sulphasalazine in the long-term maintenance of ulcerative colitis remission and Crohn's disease remission when it is confined to the colon.

There have been several conflicting reports on the use of mesalazine in the treatment of small 
bowel Crohn's disease. Rasmussen et al. found that mesalazine was not superior to placebo, ${ }^{10}$ whereas Hanauer and Wolman found mesalazine to be effective in the treatment of ileal disease. ${ }^{11,12}$ In our study Asacol was found to be less effective than sulphasalazine when the terminal ileum was involved. Recently, however, Thomson found the relapse rate to be lower in patients treated with 5-aminosalicylic acid coated with Eudraget-L. ${ }^{13}$

\section{References}

1. Misiewicz, J.J., Lennard-Jones, J.E., Connell, A.M., Parson, J.H. \& Avery-Jones, F.A. Controlled trial of sulphasalazine in maintenance therapy for ulcerative colitis. Lancet 1965, i: $185-188$

2. Baron, J.H., Connell, A.M., Lennard-Jones, J.E. \& Avery Jones, F. Sulphasalazine and salicylazosulphadimidine in ulcerative colitis. Lancet 1962, i: 1094-1096.

3. Margolin, M.L., Krumholz, M.P., Fochios, S.E. \& Korelitz, B.I. Clinical trials in ulcerative colitis: ii. Historical review. Am J Gastroenterol 1988, 83: 227-243.

4. Azad Khan, A.K., Piris, J. \& Truelove, S.C. An experiment to determine the active therapeutic moiety of sulphasalazine. Lancet 1977, ii: 892-895.

5. Das, K.M., Eastwood, M.A., McManus, J.P.A. \& Sircus, W. Adverse reactions during salicylazosulfapyridine therapy and the relation with drug metabolism and acetylator phenotype. $N$ Eng J Med 1973, 289: 491-495.

6. Haagan, N.O. \& Bondesen, S. Kinetics of 5-aminosalicylic acid after jejunal instillation in man. Br J Clin Pharmacol 1983, 16: $738-740$.

7. Dew, M.J., Hughes, P.J., Lee, M.J., Evans, B.K. \& Rhodes, J. An oral preparation to release drugs in the human colon. Br J Clin Pharmacol 1982, 14: 405-408.
Our results were based on the use of Asacol in which the acrylic resin used is Eudraget-S, a fact which might explain the apparent discrepancy between our results and those of Thomson.

The main advantage of Asacol is a decreased toxicity compared with sulphasalazine. Patients already responding well and having no problems with sulphasalazine should not benefit further from Asacol which is, if anything, more costly.

8. Mulder, C.J.J., Tytgat, G.N.J., Weterman, I.T. et al. Doubleblind comparison of slow-release 5-aminosalicylate and sulfasalazine in remission maintenance in ulcerative colitis. Gastroenterology 1988, 95: 1449-1153.

9. Donald, I.P. \& Wilkins, S.P. The value of 5-aminosalicylic acid in inflammatory bowel disease for patients intolerant to or allergic to sulphasalazine. Postgrad Med J 1985, 61: 1047-1048.

10. Rasmussen, S.N., Binder, V., Maier, K. et al. Treatment of Crohn's disease. Scan J Gastroenterol 1987, 22: 877-883.

11. Hanauer, S., Belker, M.E., Gitmick, G. et al. Multicenter placebo-controlled, dose-ranging study of oral pentasa (controlled-release mesalamine) for active Crohn's disease: preliminary results. Gastroenterology 1990, 98: A173.

12. Wolman, S.L. The use of 5-ASA in the treatment of ileal Crohn's disease. In: Trends in Inflammatory Bowel Disease Therapy. Falk Symposium no. 49. Kluwer Academic Publishers (CM), Dordrecht, 1988, p. 43.

13. International Mesalazine Study Group. Coated oral 5aminosalicylic acid versus placebo in maintaining remission of inactive Crohn's disease. Aliment Pharmacol Ther 1990, 4: $55-64$. 